\author{
Zuzanna Kowalska, Filip Pniewski, Adam Latąa \\ Instytut Oceanografii \\ Wydziat Oceanografii i Geografii \\ Uniwersytet Gdański \\ Pitsudskiego 46, 81-378 Gdynia \\ E-mail: zuzannakowalska0@gmail.com
}

\title{
BARKODING DNA - NOWOCZESNE PODEJŚCIE DO IDENTYFIKACJI ORGANIZMÓW
}

\section{PROBLEMY Z OZNACZANIEM TAKSONÓW}

Jednym $z$ najważniejszych aspektów badań biologicznych jest poznanie i opisanie różnorodności organizmów. Od wieków naukowcy borykają się $z$ problemami, które dotycza ustalenia tożsamości badanego organizmu. Nie jest to łatwe, ponieważ plastyczny fenotyp i zmienność genetyczna wykorzystywane do identyfikacji gatunków, moga prowadzić do błędnych wyników (WAUGH 2007, VALENTINI i współaut. 2009a).

Prawidłowa identyfikacja gatunków wymaga niezwykle szerokiej wiedzy $z$ zakresu morfologii i anatomii, a coraz częściej także $z$ innych dziedzin biologii (genetyki, fizjologii, biochemii etc.). Klasycznym narzędziem pracy systematyków sa klucze do oznaczania organizmów, których zasadniczym zadaniem jest umożliwienie ich szybkiego i łatwego rozróżniania. Maja one jednak swoje ograniczenia, a często sa na tyle skomplikowane i niejednoznaczne, że osoba nieposiadajaca odpowiedniej wiedzy $z$ zakresu taksonomii często nie jest w stanie dokładnie zidentyfikować obiektu swoich badań. Co więcej, również specjaliści popełniaja błędy $\mathrm{w}$ diagnozowaniu taksonomicznym. Ponadto, klucze do oznaczania organizmów na podstawie cech morfologicznych sa często skuteczne tylko w przypadku określonego stadium lub płci i zatem nie sa w pełni uniwersalnym narzędziem (HEBERT i współaut. 2003, PACKER i współaut. 2009, VALENTINI i współaut. 2009a), a w przypadku fragmentów organizmu jego identyfikacja jest zazwy- czaj niemożliwa (PACKER i współaut. 2009). Dodatkowo, w wielu grupach organizmów występuja gatunki kryptyczne (niemal morfologicznie identyczne, zazwyczaj blisko spokrewnione, ale izolowane rozrodczo) i nieopisane (KNowlTon 1993), dlatego skuteczność kluczy w tym przypadku jest niska. Szacuje się, że na świecie wystẹpuje ponad $10 \mathrm{mi}-$ lionów gatunków (HAMMOND 1992), z których tylko stosunkowo niewielki ułamek został zidentyfikowany (HEBERT i współaut. 2003, NEWMASTER i współaut. 2006, SACHITHANANDAM i współaut. 2015). Dlatego zaistniała potrzeba stworzenia nowego podejścia do oznaczania organizmów, dzięki któremu możliwe będzie, przy mniejszych nakładach finansowych i czasowych, odkrycie i opisanie wielu nowych gatunków i jednoznaczne identyfikowanie poszczególnych osobników.

\section{NOWY SYSTEM IDENTYFIKACJI ORGANIZMÓW}

Ograniczenia morfologicznej identyfikacji gatunków wywołały potrzebe nowego podejścia do rozpoznawania organizmów i stworzenia systemu, który wykorzystywałby informację genetyczna jako swoisty znacznik każdego osobnika. System taki w swojej istocie miałby być wiarygodny, jednolity $\mathrm{w}$ skali globalnej, latwy do wykorzystania nawet przez naukowców nieposiadajacych wyspecjalizowanej wiedzy na temat taksonomii, a także osoby pracujące, $\mathrm{np}$. w instytucjach ochrony i monitorowania środowiska. Wszystkie te warunki spełniała idea Heberta 
(HEBERT i współaut. 2003). Badacz zaproponował system, który swoja prostota i uniwersalnością miał przypominać identyfikację produktów w sklepach. Po opublikowaniu przez Heberta (HEBERT i współaut. 2003) idei identyfikacji organizmów przy użyciu barkodów DNA, odbyło się wiele debat i dyskusji, których efektem był projekt Barcode of Life Initiative (BOLI) (MIREK i współaut. 2007). Głównym jego założeniem była standaryzacja barkodów DNA w skali globalnej. Realizacja tego projektu zajęło się CBOL (ang. Consortium for the Barcode of Life) (RATNASINGHAM i HEBERT 2007, VALENTINI i współaut. 2009a). Konsorcjum zostało uruchomione w maju 2005 r. i obejmuje obecnie ponad 150 organizacji z 45 krajów (STOECKLE i HEBERT 2008). CBOL wspiera rozwój międzynarodowej współpracy badaczy, niezbędnej do zbudowania w ciagu najbliższych 20 lat biblioteki kodów kreskowych dla wszystkich znanych organizmów eukariotycznych (RATNASINGHAM i HEBERT 2007). Działania CBOL doprowadziły do ustanowienia formalnych wytycznych, które musza zostać spełnione w celu wytypowania barkodów DNA. Sekwencje musza pochodzić $z$ wyznaczonego regionu genu, muszą spełniać standardy jakości i pochodzić $z$ okazu/szczepu, którego przynależność taksonomiczna może być powiązana $z$ taksonami dostępnymi w bazach danych (COSTA i CARVAlHo 2007).

\section{CZYM JEST BARKODING DNA?}

Idea barkodingu DNA jest prosta. Każdy organizm posiada w swoim genomie informację genetyczna, która może zostać wykorzystana jako znacznik organizmu i umożliwi jego identyfikację (HEBERT i współaut. 2003, NEWMASTER i współaut. 2006). Barkod DNA to krótka sekwencja lub kilka sekwencji w danym locus lub kilku loci, która umożliwi ustalenie tożsamości badanego organizmu (HEBERT i współaut. 2003, MORITz i CiCERO 2004). Sekwencja wykorzystana do barkodingu DNA musi spełniać określone kryteria. Po pierwsze, wykazywać niską zmienność w obrębie gatunków, a równocześnie wysoka na poziomie międzygatunkowym. Po drugie, taka sekwencja musi być krótka, aby fragment mógł być sekwencjonowany w pojedynczym odczycie. Po trzecie, sekwencja powinna być oflankowana przez wysoce konserwowane regiony, dzięki którym możliwe będzie opracowanie uniwersalnych starterów i standaryzacja barkodów DNA dla poszczególnych grup organizmów (KRESS i współaut. 2005). Ostatnim i bardzo ważnym kryterium jest występowanie w genomie w dużej liczbie kopii. Cecha ta ma ogromne znaczenie $\mathrm{w}$ pracy $\mathrm{z}$ niewielkimi lub częśsiowo zdegra- dowanymi fragmentami tkanek, niewielkimi ilościami komórek, a także materiałami kopalnymi. Im większa liczba kopii sekwencji docelowej w genomie, tym większa szansa, że chociaż część $z$ nich zachowała się w stanie nienaruszonym (KRESS i współaut. 2005, NEWMASTER i współaut. 2006, KRESS i ERICKSON 2008, PEČNIKAR i BUZAN 2014).

\section{BARKODY DNA WYKORZYSTYWANE DO IDENTYFIKACJI ORGANIZMÓW}

Świat zwierzęcy jest bardzo różnorodny. Obecne sa w nim zarówno organizmy duże, jak i drobne, wodne i lądowe. Nie jest więc zaskakujace, że zwierzęta, które widać gołym okiem, sa lepiej poznane, ze względu na dobrze widoczne cechy morfologiczne. Natomiast mniejsi przedstawiciele w większości sa nadal słabo opisani (WAUGH 2007). Intensyfikacja procesu katalogowania istniejacych gatunków jest wywołana, obok nastawienia poznawczego, obserwowanym obecnie masowym ginięciem organizmów, które w dużej mierze ma podłoże antropogeniczne. Tempo tego procesu sprawia, że istnieje potrzeba przyspieszenia i ułatwienia procesów rozpoznawania i identyfikacji taksonów, a ze względu na skalę problemu konieczne jest zastosowanie nowych metod. Do tego zadania idealnie nadaje się barkoding DNA.

Mitochondrialny DNA (mtDNA) ma kilka zalet w porównaniu do jądrowego DNA. Tempo mutacji DNA jest odwrotnie proporcjonalne do wielkości genomu (DRAKE 1991, SINDEN 2012). W zwiazku $z$ tym jądrowy DNA ulega względnie powolnej mutacji w stosunku do mtDNA i $z$ tego powodu wymagałby znacznie dłuższej sekwencji nukleotydów niż jest to konieczne w przypadku mtDNA, aby zapewnić barkod DNA zdolny do różnicowania gatunków (WAUGH 2007).

Obecnie, jako standardowy barkod DNA dla wszystkich grup zwierzat, wykorzystywany jest fragment genu kodujacego enzym, oksydaze cytochromu c (Cox1). Enzym ten jest dużym transbłonowym białkiem znajdującym się $\mathrm{w}$ mitochondrium, wysoce konserwatywny w przypadku gatunków, które wykorzystują fosforylację oksydacyjna w metabolizmie oddychania (BRUNORI i współaut. 1987, OSTERMEIER i współaut. 1996). Co więcej, insercje $\mathrm{i}$ delecje w przypadku tego markera sa rzadkie (BLAXTER 2004). Cox1 ma uniwersalne startery umożliwiajace identyfikacje przedstawicieli większości, jeśli nie wszystkich, gromad zwierzęcych. Dodatkowo, ewolucja tego genu jest wystarczajaco szybka, aby umożliwić rozróżnienie nie tylko blisko spokrewnionych gatunków, ale także grup filogeograficznych w obrębie jednego gatunku (HEBERT i współaut. 2003). 
Marker Cox1 wykorzystywany jest również w identyfikacji grzybów. Jednak problemy $z$ występowaniem intronów $i$ brak rozdzielczości na poziomie międzygatunkowym uniemożliwiaja jego uniwersalne zastosowanie (KRESS i współaut. 2015). Dlatego ITS (ang. internal transcribed spacer), czyli niekodująca domena zlokalizowana pomiędzy mała podjednostka rybosomu a genami rRNA podjednostki dużej (YANG i współaut. 2012), została przyjęta jako standardowy barkod DNA do identyfikacji grzybów (SEIFERT 2009, KRESS i współaut. 2015). W przypadku roślin lądowych sekwencja Cox1, standardowa dla królestwa zwierzat, wykazuje niewystarczajacca zmienność (KRESS i współaut. 2005), jednak może być wykorzystywana w przypadku niektórych grup glonów (SAUNDERS 2005). Mitochondrialne DNA roślin nie jest najlepszym źródłem sekwencji, które moga być wykorzystane do barkodingu DNA ze względu na to, że występuja $\mathrm{w}$ nim częste rearanżacje i wymiana genów $z$ genomem jądrowym, a standaryzacja takich sekwencji wymaga wykorzystania tylko tych o stabilnej strukturze (HEBERT i współaut. 2003, KRESS i współaut. 2015). Proponowana sekwencja standardowa dla królestwa roślin był ITS. Została ona jednak wykluczona ze względu na możliwość występowania różnych kopii tej domeny u jednego organizmu oraz niejasności co do przebiegu jej ewolucji (MIREK i współaut. 2007). Ze względu na to, że geny jądrowego DNA występuja w zbyt małej liczbie kopii, aby mogły być wykorzystane do sekwencjonowania zdegradowanego DNA, zaczęto wykorzystywać chloroplastowe DNA, które w komórkach roślinnych występuje w wielu kopiach. Przy obecnym stanie wiedzy nie można wskazać idealnej sekwencji barkodu DNA w żadnym $z$ genomów roślinnych, dlatego koniecznym jest użycie kilku sekwencji o niższej zmienności, które wspólnie utworzą barkod DNA (KREss i współaut. 2005). Niedawno zaproponowano uniwersalny barkod DNA pozwalający na identyfikację organizmów fotosyntetyzujących. W tym celu SHERWOOD i PRESTING (2007) użyli fragmentu plastydowego genu 23S rDNA jako uniwersalnego markera dla roślin zauważając, że dzięki pojedynczej parze starterów wykorzystanej do reakcji PCR można uzyskać sekwencje $z$ szerokiego zakresu taksonomicznego, w tym roślin wyższych, mikroglonów, a nawet cyjanobakterii. Marker ten cechuje się bardzo dużym sukcesem amplifikacji, natomiast użyteczność sekwencjonowania genu 23S rDNA jest potencjalnie ograniczona ze względu na stosunkowo mała ilość informacji w bazach danych.

\section{REFERENCYJNYJNE BAZY DANYCH}

Jednym $z$ najważniejszych elementów inicjatywy barkodingu DNA jest budowa publicznej biblioteki referencyjnej zawierającej identyfikatory taksonów, która można wykorzystać do przypisania nieznanych osobników znanym gatunkom. Obecnie istnieja dwie główne bazy danych zawierające sekwencje barkodów DNA, które wypełniaja tę rolę: BoLD i GenBank.

Dzięki systemom informatycznym, takim jak BoLD (ang. Barcode of Life Database), wspomagane jest pozyskiwanie, przechowywanie, analiza i publikacja rekordów barkodów DNA (STRUGNELl i LindGRen 2007). Program ten zapewnia zintegrowana platformę bioinformatyczna, która obsługuje wszystkie etapy ścieżki analitycznej, od pobrania próbki do ściśle zweryfikowanej biblioteki kodów kreskowych (STOECKLE i HEBERT 2008). BoLD jest bezpłatnie dostępny dla każdego badacza zainteresowanego barkodingiem DNA i zawiera ponad 6 milionów sekwencji barkodów DNA (www.boldsystems.org). Zapewniajac wyspecjalizowane usługi, ułatwia zestawianie rekordów spełniających standardy wymagane do uzyskania barkodu DNA w globalnych bazach danych sekwencji (COSTA i CARVAlHo 2007). Dzięki internetowemu systemowi dostarczania danych stanowi cenne wsparcie projektów badawczych (RATNASINGHAM i HEBERT 2007).

Referencyjna baza danych GenBank zawiera ponad 200 milionów sekwencji pochodzących $z$ różnych organizmów, gromadzonych głównie przez bezpośrednie przekazywanie sekwencji $z$ poszczególnych laboratoriów i projektów sekwencjonowania na dużą skalę (w tym $z$ projektów dotyczących całych genomów, a także pochodzacych $z$ pobierania próbek środowiskowych) (BENSON i współaut. 2018). Stała wymiana danych $z$ European Nucleotide Archive i Japan Data Bank zapewnia zasięg o charakterze globalnym (COSTA i CARVALHO 2007, BENSON i współaut. 2018). GenBank jest dostępny za pośrednictwem bazy danych NCBI (ang. National Center for Biotechnology Information; największa baza informacji $z$ dziedziny nauk biomedycznych), która integruje dane $z$ głównych baz danych sekwencji DNA i białek wraz $z$ taksonomia, genomami, mapowaniem i informacjami o strukturze białka (PRUITT i współaut. 2008) oraz literatura biomedyczna za pośrednictwem PubMed (angielskojęzyczna wyszukiwarka internetowych baz danych obejmujacca artykuły $z$ dziedziny medycyny i nauk biologicznych). Algorytm BLAST zapewnia wyszukiwanie podobieństwa sekwencji w GenBank i innych bazach danych. NCBI oferuje również szeroki wa- 
chlarz usług wyszukiwania i analizy w oparciu o dane GenBank (SHARMA i współaut. 20018). Baza danych GenBank i powiazane zasoby sa ogólnodostępne na stronie głównej NCBI (BENSON i współaut. 2018). Każdego roku przybywa coraz więcej sekwencji referencyjnych, co pokazuja badania Bensona $z$ lat 1994-2018. Dane z 1994 r. (BENSON i współaut. 1994) informuja, że baza danych GenBank zawierała 182753 sekwencji, zaś dane $z 2018$ r. pokazuja znaczny wzrost do ponad 200 milionów sekwencji. Dzięki referencyjnym bazom danych możliwe jest zidentyfikowanie badanych taksonów. Im więcej informacji, tym szybsza i wiarygodniejsza jest interpretacja uzyskanych wyników.

\section{MATERIAE I JEGO ANALIZA}

Materiał do analiz laboratoryjnych barkodingu DNA może pochodzić $z$ kolekcji różnych instytucji naukowych, może być to materiał środowiskowy (woda, powietrze, gleba, osady), a także materiał kopalny (KRESS i współaut. 2015). W próbach środowiskowych znajduja się związki zarówno organiczne, jak i nieorganiczne. Moga w nim być obecne również żywe osobniki (tj. mikroorganizmy lub małe makroorganizmy) i resztki makroorganizmów zdeponowane w okolicy miejsca pobierania próbek (TABERLET i współaut. 2012).

Do tej pory próbki środowiskowe były wykorzystywane głównie do badania zbiorowisk mikroorganizmów. W tym przypadku można uzyskać sekwencje DNA kilkuset par zasad, ponieważ DNA dobrej jakości ekstrahuje się $z$ żywych mikroorganizmów (TABERLET i współaut. 2012). Próbki środowiskowe moga być również przydatne do charakteryzowania różnorodności gatunków roślin lub zwierzat $w$ ekosystemach (HAJIBABAEI i współaut. 2007). W tym przypadku DNA często pochodzi $z$ martwych makroorganizmów, w większości przypadków materiał jest wysoce zdegradowany. Nowe techniki sekwencjonowania $\mathrm{w}$ połączeniu $\mathrm{z}$ uniwersalnymi starterami, które wzmacniaja krótkie fragmenty, umożliwiaja identyfikację różnych taksonów w takim materiale. Poniżej podano przykładowe prace przeprowadzone przy wykorzystaniu różnego rodzaju próbek środowiskowych:

- badania zbiorowisk makroorganizmów (przy użyciu próbek wody) bez konieczności obserwacji tych osobników w środowisku (FICETOLA i współaut. 2008);

- badania prowadzone na wiecznej zmarzlinie i rdzeniach lodowych, do opisu gatunków wymarłych (JøRGENSEN i współaut. 2012, BELLEMAIN i współaut. 2013);
- badania występowania i struktury genetycznej organizmów inwazyjnych $\mathrm{w}$ osadach (PORCO i współaut. 2013);

- badania dotyczace identyfikacji gatunków inwazyjnych (różne rodzaje prób środowiskowych w tym różne obiekty nieożywione) (ARMSTRONG i BALL 2005, BRISKI i współaut. 2011, DEJEAN i współaut. 2012).

W przypadku osadów bądź tkanek zwierzęcych zaleca się wcześniejszą liofilizację materiału (PRIGIGALLO i współaut. 2015). Jeżeli analizom poddawane sa rośliny, to wskazane jest wcześniejsze zamrażanie i rozmrażanie materiału, umożliwiające efektywniejsza degradację ścian komórkowych (SAHU i współaut. 2012). Traktowanie materiału na potrzeby barkodingu jest identyczne jak w przypadku innych analiz genetycznych (Ryc. 1). Niewielka ilość tkanki czy hodowli komórkowej jest wykorzystywana do izolacji genomowego DNA przy użyciu różnych zestawów dostępnych na rynku biotechnologicznym. Następnie, używając uniwersalnych par starterów bąź kombinacji kilku starterów, powiela się pożądany fragment $\mathrm{w}$ łańcuchowej reakcji polimerazy (PCR). Zamplifikowany materiał poddawany jest elektroforezie na żelu agarozowym w celu sprawdzenia jakości jego produktów, które poddaje się sekwencjonowaniu. W celu identyfikacji danego organizmu zwykle wykonywane jest sekwencjonowanie metoda SANGERA i współaut. (1977), która wykorzystuje właściwości dideoksynukleotydôw (ddNTP), czyli nukleotydów nieposiadających grupy hydroksylowej, a jedynie wodór w pozycjach 2' i 3' cukru. Przyłaczenie dideoksynukleotydu do nowo syntetyzowanego DNA hamuje wydłużanie nici, $z$ powodu braku grupy hydroksylowej w pozycji 3' pentozy, niezbędnej do utwo-

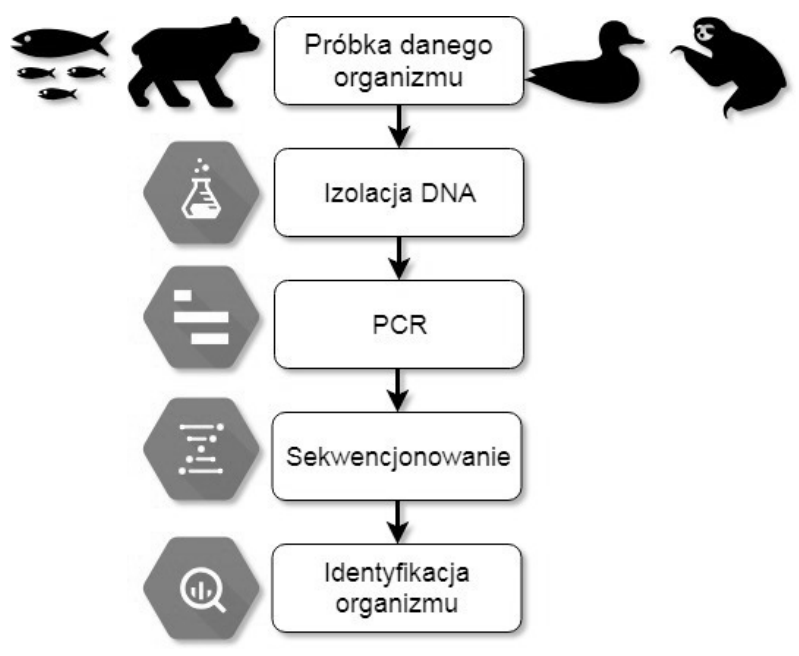

Ryc. 1. Identyfikacja gatunków przy użyciu technik molekularnych. 
rzenia wiazania fosfodiestrowego (SANGER i współaut. 1977). Dzięki temu uzyskuje się sekwencje, które moga zostać porównywane z dostępnymi w bazach danych. Algorytmy, np. BLAST, pozwalaja wyszukiwać sekwencje najbardziej podobne do uzyskanych docelowych, co często umożliwia zidentyfikowanie pojedynczego organizmu ze $100 \%$ pewnością.

W ostatnim dziesięcioleciu przeprowadzono różnorodne badania mające na celu opracowanie alternatywnych podejść do analizy różnorodności biologicznej za pomoca metod opartych na sekwencjach DNA, takich jak filogenetyka molekularna i barkody DNA (HAJIBABAEI i współaut. 2007). Ciagłe rozwijanie i łaczenie bibliotek referencyjnych barkodów DNA zapewnia bazę danych dla systemu identyfikacji opartego na DNA. Zastosowanie metod sekwencjonowania nowej generacji (NGS) w badaniach różnorodności biologicznej, może dodatkowo rozszerzyć zastosowanie informacji o DNA do biomonitoringu $\mathrm{w}$ nieosiagalnej dotąd skali. Technologie sekwencjonowania nowej generacji charakteryzuja się ogromna przepustowościa, co znacznie obniża koszt odczytywania kolejności nukleotydów, w porównaniu ze standardowa metoda Sangera (SHOKRALLA i współaut. 2012). Analiza eDNA (środowiskowego; ang. e-environment) przy użyciu barkodów DNA jest kluczowym zastosowaniem sekwencjonowania NGS w badaniach ekologicznych. Dostęp do ogromnej liczby sekwencji i dalsze ulepszanie odczytywania długości i przepustowości różnych platform sekwencyjnych, prowadza do lepszego poznania bioróżnorodności badanych próbek środowiskowych. Nowe technologie szybko się rozwijaja i stwarzaja możliwości znacznego rozwoju wiedzy ekologicznej i badań środowiskowych.

\section{WYKORZYSTANIE BARKODINGU DNA W BADANIACH ŚRODOWISKOWYCH}

Barkoding DNA może również odgrywać ważną rolę w monitoringu i ocenie różnorodności biologicznej, zarówno obecnych, jak i dawnych zbiorowisk roślinnych i zwierzęcych (HAJIBABAEI i współaut. 2007). Jest to metoda tańsza i szybsza od tradycyjnej inwentaryzacji gatunków w danym ekosystemie (VALENTINI i współaut. 2009a). Metoda ta umożliwia ocenę bioróżnorodności w próbkach środowiskowych (osady, gleba czy woda) przez identyfikację taksonów na podstawie obecnych w nich śladów DNA (FICETOLA i współaut. 2008, GRoss 2012). Barkoding DNA może zastąpić rutynowa identyfikację prowadzona przez wielu systematyków, których praca mogłaby się koncentrować raczej na identyfikacji wzorców referencyjnych do ustalenia wiarygodności baz danych.
Charakterystyka ekosystemów występujacych w przeszłości na podstawie danych kopalnych jest bardzo trudna ze względu na właściwości próbek. W większości przypadków identyfikacja morfologiczna na poziomie gatunku jest bardzo trudna lub wręcz niemożliwa (RAWLENCE i współaut. 2014, THOMSEN i WILLERSLEV 2015). W takim przypadku narzędzia molekularne i barkoding DNA mogłyby pomóc naukowcom w dokładnym opisaniu bioróżnorodności zbiorowisk roślinnych i zwierzęcych oraz rekonstrukcji ekosystemów, nawet $z$ dalekiej przeszłości (Thomsen i Willerslev 2015). Podejście molekularne można dodatkowo zastosować do badania diety wymarłych zwierząt (VALENTINI i współaut. 2009b).

Badanie sieci pokarmowych i ich dynamiki ma zasadnicze znaczenie dla zrozumienia, w jaki sposób odżywianie różnych gatunków może wpływać na funkcjonowanie ekosystemu jako całości (SOININEN i współaut. 2009, CARREON-MARTINEZ i HEATH 2010). Ponadto, poznanie sposobu odżywiania ma kluczowe znaczenie w przypadku zagrożonych gatunków. Dokładna znajomość ich diety może wskazywać na zasoby środowiskowe niezbędne dla projektowania skutecznych strategii ich ochrony (VALENTINI i współaut. 2009b). Barkody DNA umożliwiaja zatem poznanie diety osobnika na podstawie analizy kału lub zawartości żołądka (SOININEN i współaut. 2009, VALENTINI i współaut. 2009b). Jest to szczególnie pomocne, gdy żywności nie da się zidentyfikować na podstawie kryteriów morfologicznych.

\section{INNE ZASTOSOWANIA BARKODINGU DNA}

Narzedzie to ma szerokie zastosowania praktyczne. Jest przydatne w naukach medycznych w oznaczaniu alergenów u ludzi. Pozwalaja także bardzo szybko zidentyfikować organizmy wywołujace zatrucia pokarmowe (grzyby, rośliny, zwierzęta) (WoNG i HANNER 2008, GRZYWACZ i BOGDANOWICZ 2009). Barkody DNA można także wykorzystać w badaniach służących określaniu pokrewieństwa lub rodzicielstwa (GRZYWACZ i BOGDANOWICZ 2009).

Bezpieczeństwo i jakość żywności stanowią obecnie poważny problem. Pojawia się on często w mediach, prowokujacc dyskusję publiczna. Istnieje rosnace zapotrzebowanie na poprawę kontroli jakości, a tym samym skierowanie badań naukowych w kierunku opracowania niezawodnych narzedzi molekularnych do analizy żywności. Barkoding DNA jest szeroko stosowanym systemem molekularnym, który może identyfikować próbki biologiczne i służy do identyfikacji zarówno 
surowców, jak i przetworzonej żywności. Posiada on również zastosowanie w identyfikacji nadużyć handlowych (WONG i HANNER 2008, GALIMBERTI i współaut. 2013).

Wykorzystanie analizy DNA w dochodzeniach sadowych dotyczacych przemocy wobec zwierzat i ochrony różnorodności biologicznej jest obecnie powszechne, a zbrodnie, takie jak nielegalny przemyt, kłusownictwo i bezprawny handel chronionymi gatunkami, są coraz częściej badane za pomoca dowodów opartych na analizie DNA (DALTON i KotZe 2011, IYengar 2014). Ponadto, barkody DNA znajduja zastosowanie także w entomologii sadowej. Identyfikacja nekrofagicznych owadów może pomóc w otrzymaniu szczegółowych informacji dotyczacych czasu i miejsca zgonu. Wyniki uzyskane za pomoca barkodów DNA moga być także pomocne w przypadku podejrzenia morderstwa (MEIKLEJOHNI współaut. 2013, ROLO i współaut. 2013).

\section{CZY BARKODING DNA ZASTAPI TRADYCYJNE METODY IDENTYFIKACJI?}

Barkoding DNA ma stanowić mocne uzupełnienie badań taksonomicznych, mając na celu wyparcia tradycyjnych metod oznaczania gatunków. W przyszłości taksonomowie i ekolodzy będa mogli prowadzić badania środowiskowe bez potrzeby używania do oznaczeń kluczy morfologicznych. Barkoding DNA umożliwi oznaczanie różnorodności DNA w obrębie morfologicznie nierozpoznanych gatunków, a także stanie się genetycznym kluczem do szybkiej identyfikacji opisanych już wcześniej taksonów (EBACH i HOLDREGE 2005). Linneuszowski system taksonomiczny stanie się bardziej dostępny, co przyniesie korzyści ekologom, działaczom zajmującym się ochrona przyrody oraz agencjom zajmującym się zwalczaniem szkodników, gatunków inwazyjnych i bezpieczeństwem żywności (HEBERT i GREGORY 2005). Dzięki barkodom DNA możliwy będzie latwy dostęp do nazw i cech biologicznych dowolnego gatunku na naszej planecie. Barkoding DNA przyspieszy tempo identyfikacji organizmów, umożliwiając systematykom szybkie sortowanie okazów i wykrywanie tych taksonów, które moga reprezentować gatunki dotychczas nieopisane. Barkody DNA oferuja uczonym możliwość znacznego rozszerzenia baz danych, w tym uzyskania globalnego spisu taksonów oraz pełniejszego poznania różnorodności życia.

\section{PODSUMOWANIE}

Nowe narzędzia do identyfikacji taksonów sa niezwykle potrzebne. Wraz ze wzrostem antropopresji ekosystemy ulegaja zmianom, które prowadzić moga do wymierania gatunków i utraty bioróżnorodności. Koniecznym jest skatalogowanie i rozpoznanie bogactwa gatunkowego danych ekosystemów, aby móc monitorować zachodzace $\mathrm{w}$ nim zmiany i próbować im zapobiec. Umożliwi to prosty, efektywny system - barkoding DNA, narzędzie służące do opisu istniejących gatunków, przydatne także $\mathrm{w}$ identyfikacji zupełnie nowych taksonów. Ze względu na wiele ograniczeń wynikających $z$ morfologicznego diagnozowania taksonomicznego, tradycyjne metody sa coraz częściej uzupełniane o znaczniki molekularne. Istnieja liczne zastosowania dla barkodów DNA, a część $z$ nich zostanie $z$ pewnością w przyszłości dopracowana, ponieważ molekularna ocena różnorodności organizmów odgrywa coraz większa rolę w kontrolowaniu $\dot{i}$ wykrywaniu gatunków inwazyjnych, identyfikacji organizmów $\mathrm{w}$ celu monitorowania środowiska oraz testowania komercyjnych produktów pochodzenia zwierzęcego czy roślinnego.

\section{Streszczenie}

$\mathrm{Na}$ świecie występuje wiele gatunków, z których jeszcze nie wszystkie sa poznane i opisane. Tradycyjne techniki oznaczania taksonów, głównie przy wykorzystaniu cech morfologicznych i odpowiednich kluczy, maja istotne ograniczenia. Dlatego też istnieje potrzeba nowego podejścia do diagnozowania taksonomicznego organizmów i zastosowania metod, które będa łatwe, szybkie, tanie oraz wiarygodne. Barkoding DNA idealnie wpasowuje się w tę potrzebę. Jest to system identyfikacji gatunków w oparciu o jedna lub kilka krótkich, charakterystycznych dla danego organizmu sekwencji DNA. Może być on wykorzystany do ustalenia tożsamości znanych gatunków, bądź też do poznania tych nieodkrytych. Dodatkowo system ten może być wykorzystany w paleoekologii, badaniach różnorodności biologicznej i sieci troficznych oraz może mieć wiele innych zastosowań. Niniejsza praca przedstawia ideę barkodingu DNA, standardowe markery wykorzystywane do identyfikacji organizmów, a także możliwości wykorzystania barkodów DNA w nauce oraz w celach praktycznych i komercyjnych.

\section{LITERATURA:}

ARMSTRONG K. F., BALL S. L., 2005. DNA barcodes for biosecurity: invasive species identification. Philosoph. Transact. Royal Soc. London B: Biol. Sci. 360, 1813-1823.

Bellemain E., Davey M. L., Kauserud H., EpP L. S., Boessenkool S., Coissac E., TABerlet P., 2013. Fungal palaeodiversity revealed using high-throughput metabarcoding of ancient DNA from arctic permafrost. Environ. Microbiol. 15, 1176-1189.

Benson D. A., Boguski M., LiPMAN D. J., OsTELL J., 1994. GenBank. Nucl. Acids Res. 22, 3441.

Benson D. A., Cavanaugh M., Clark K., KARSCH-MiZRACHI I., OSTELL J., PRUITT K. D., SAYers E. W., 2018. GenBank. Nucl. Acids Res. 46, D41-D47. 
BLAXTER M. L., 2004. The promise of a DNA taxonomy. Philosoph. Transact. Royal Soc. London B: Biol. Sci. 359, 669-679.

BRISKI E., CRISTESCU M. E., BAILEY S. A., MACISAAC H. J., 2011. Use of DNA barcoding to detect invertebrate invasive species from diapausing eggs. Biol. Invas. 13, 1325-1340.

BRUnori M., Antonini G., Malatesta F., SARTi P., WILSON M. T., 1987. Cytochrome-c oxidase. FEBS J. 169, 1-8.

CarReOn-Martinez L., Heath D. D., 2010. Revolution in food web analysis and trophic ecology: diet analysis by DNA and stable isotope analysis. Mol. Ecol. 19, 25-27.

Costa F. O., CARvalho G. R., 2007. The Barcode of Life Initiative: synopsis and prospective societal impacts of DNA barcoding of fish. Genom. Soc. Policy 3, 29.

DALTON D. L., KOTZE A., 2011. DNA barcoding as a tool for species identification in three forensic wildlife cases in South Africa. Forensic Sci. Int. 207, e51-e54.

Dejean T., Valentini A., Miquel C., Taberlet P., Bellemain E., Miaud C., 2012. Improved detection of an alien invasive species through environmental DNA barcoding: the example of the American bullfrog Lithobates catesbeianus. J. Appl. Ecol. 49, 953-959.

DRAKE J. W., 1991. A constant rate of spontaneous mutation in DNA-based microbes. Proc. Natl. Acad. Sci. 88, 7160-7164.

EBACH M. C., HoldREGE C., 2005. DNA barcoding is no substitute for taxonomy. Nature 434, 697.

Ficetola G. F., Miaud C., Pompanon F., TaberLET P., 2008. Species detection using environmental DNA from water samples. Biol. Lett. 4, 423-425.

Galimberti A., De Mattia F., Losa A., Bruni I., FEDERICI S., CASIRAGHI M., LABRA M., 2013. DNA barcoding as a new tool for food traceability. Food Res. Int. 50, 55-63.

Gross M., 2012. Barcoding biodiversity. Curr. Biol. 22, 73-76.

GrzywaCZ A., Bogdanowicz W., 2009. Możliwości wykorzystania barkodingu $w$ ochronie przyrody. Studia i Materiały Centrum Edukacji Przyrodniczo-Leśnej 11, 38-44.

Hajibabaei M., Singer G. A., Clare E. L., Hebert P. D., 2007. Design and applicability of DNA arrays and DNA barcodes in biodiversity monitoring. BMC Biol. 5, 24.

HAMMOND P., 1992. Species inventory. [W:] Global biodiversity: status of the earth's living resources. GROOMBRIDGE B. (red.). London, Chapman \& Hall, 17-39.

HEBerT P. D., GRegory T. R., 2005. The promise of DNA barcoding for taxonomy. Syst. Biol. 54, 852-859.

HeberT P. D., Cywinska A., Ball S. L., 2003. Biological identifications through DNA barcodes. Proc. Royal Soc. London B: Biol. Sci. 270, 313-321.

IYENGAR A., 2014. Forensic DNA analysis for animal protection and biodiversity conservation: a review. J. Nat. Conserv. 22, 195-205.

Jørgensen T., Haile J., Möller P. E. R., ANDREEV A., BOESSENKOOL S., RASMUSSEN M., BIGELOW N. H., 2012. A comparative study of ancient sedimentary DNA, pollen and macrofossils from permafrost sediments of northern Siberia reveals long-term vegetational stability. Mol. Ecol. 21, 1989-2003.

KNOWLTON N., 1993. Sibling species in the sea. Ann. Rev. Ecol. Syst. 24, 189-216.
KRESS W. J., ERICKSON D. L., 2008. DNA barcodes: genes, genomics, and bioinformatics. Proc. Natl. Acad. Sci. USA 105, 2761-2762.

KRESS W. J., WURDACK K. J., ZiMMER E. A., WEIGT L. A., JANZEN D. H., 2005. Use of DNA barcodes to identify flowering plants. Proc. Natl. Acad. Sci. USA 102, 8369-8374.

Kress W. J., García-Robledo C., URIARTe, M., ERICKSON D. L., 2015. DNA barcodes for ecology, evolution, and conservation. Trends Ecol. Evol. 30, 25-35.

MEIKLEJOHN K. A., WALlMAN J. F., DOWTON M., 2013. DNA barcoding identifies all immature life stages of a forensically important flesh fly (Diptera: Sarcophagidae). J. Forensic Sci. 58, 184-187.

MireK Z., BienieK W., SzTORC A., 2007. Barkoding DNA-nowe narzędzie do opisu

bioróżnorodności. Wiad. Botan. 51, 41-50.

MORITZ C., CICERO C., 2004. DNA barcoding: promise and pitfalls. Publ. Library Sci. Biol. 2, 1529-1531.

NeWMaster S. G., FAZEKas A. J., Ragupathy S., 2006. DNA barcoding in land plants: evaluation of $\mathrm{rbcL}$ in a multigene tiered approach. Botany 84, 335-341.

Ostermeier C., IwATA S., Michel H., 1996. Cytochrome c oxidase. Curr. Opin. Struct. Biol. 6, 460-466.

Packer L., GibBs J., Sheffield C., Hanner R., 2009. DNA barcoding and the mediocrity of morphology. Mol. Ecol. Resour. 9, 42-50.

PEČNIKAR Ž. F., BUZAN E. V., 2014, 20 years since the introduction of DNA barcoding:

from theory to application. J. Appl. Genet. 55, 43-52.

Porco D., DecaËns T., Deharveng L., James S. W., SKarżyńsKi D., ERSÉus C., HEBERT P. D., 2013. Biological invasions in soil: DNA barcoding as a monitoring tool in a multiple taxa survey targeting European earthworms and springtails in North America. Biol. Invas. 15, 899-910.

Prigigallo M. I., Mosca S., Cacciola S. O., COOKE D. E. L., SchenA L., 2015. Molecular analysis of Phytophthora diversity in nursery-grown ornamental and fruit plants. Plant Pathol. 64, 1308-1319.

PRuitT K. D., TAtusova T., Klimke W., Maglott D. R., 2008. NCBI Reference Sequences: current status, policy and new initiatives. Nucl. Acids Res. 37 (Suppl. 1), D32-D36.

RATNASINGHAM S., HEBERT P. D., 2007. BOLD: The Barcode of Life Data System (http://www. barcodinglife. org). Mol. Ecol. Resour. 7, 355364.

RAWlence N. J., Lowe D. J., WoOD J. R., Young J. M., CHURCHMAN G. J., HUANG Y. T., COOPER A., 2014. Using palaeoenvironmental DNA to reconstruct past environments: progress and prospects. J. Quatern. Sci. 29, 610-626.

Rolo E. A., Oliveira A. R., DOURADO C. G., FARINHA A., REBELO M. T., DIAS D., 2013. Identification of sarcosaprophagous Diptera species through DNA barcoding in wildlife forensics. Forensic Sci. Int. 228, 160-164.

SaChithanandam V., MOHAN P. M., MuRUganandam N., 2015. DNA Barcoding of Marine Venomous and Poisonous Fish of Families Scorpaenidae and Tetraodontidae from Andaman Waters. Mar. Faunal Divers. India 351-372.

SAHU S. K., THANGARA, M., KATHIRESAN K., 2012. DNA extraction protocol for plants with high levels of secondary metabolites and polysaccharides without using liquid nitrogen and 
phenol. Int. Scholar. Res. Not. Mol. Biol. 2012, 1-6.

SANGER F., NiCKLEN S., COUlson A. R., 1977 DNA sequencing with chain-terminating inhibitors. Proc. Natl. Acad. Sci. USA 74, 54635467.

SAUNDERS G., 2005. Applying DNA Barcoding to red macroalgae: a preliminary appraisal holds promise for future applications. Proc. Royal Soc. London B: Biol. Sci. 360, 1879-1888.

SEIFERT K. A., 2009. Progress towards DNA barcoding of fungi. Mol. Ecol. Resour. 9, 83-89.

SHARMA S., CiUfo S., STARCHENKo E., DARJI D., CHLUMSKY L., KARSCH-MizRACHI I., SCHOCH C. L., 2018. The NCBI BioCollections Database. Database, doi: 10.1093/database/bay006.

SHERWOOD A. R., PRESTING G. G., 2007. Universal primers amplify a 23S rDNA plastid marker in eukaryotic algae and cyanobacteria. J. Phycol. 43, 605-608

ShOKRAlla S., Spall J. L., GiBSON J. F., HaJIBABAEI M., 2012. Next-generation sequencing technologies for environmental DNA research. Mol. Ecol. 21, 1794-1805.

SINDEN R. R., 2012. DNA structure and function. Academic, San Diego.

Soininen E. M., Valentini A., Coissac E., Miquel C., Gielly L., Brochmann C., TaBerlet P., 2009. Analyzing diet of small herbivores: the efficiency of DNA barcoding coupled with high-throughput pyrosequencing for deciphering the composition of complex plant mixtures. Front. Zool. 6, 16.

Stoeckle M. Y., HeberT P. D., 2008. Barcode of life. Sci. Am. 299, 82-89.
STRUGNEll J. M., LINDGREN A. R., 2007. A barcode of life database for the Cephalopoda? Considerations and concerns. Rev. Fish Biol. Fisher. 17, 337-344.

Taberlet P., Coissac E., Hajibabaei M., RieseBERG L. H., 2012. Environmental DNA. Mol. Ecol. 21, 1789-1793.

Thomsen P. F., Willerslev E., 2015. Environmental DNA-An emerging tool in conservation for monitoring past and present biodiversity. Biol. Conserv. 183, 4-18.

VAlENTINI A., POMPANON F., TABERlet P., 2009a. DNA barcoding for ecologists. Trends Ecol. Evol. 24, 110-117.

Valentini A., Miouel C., Nawaz M. A., Bellemain E. V. A., CoIssac E., Pompanon F., Swenson J. E., 2009b. New perspectives in diet anal ysis based on DNA barcoding and parallel pyrosequencing: the trnL approach. Mol. Ecol. Resour. 9, 51-60.

WAUGH J., 2007. DNA barcoding in animal species: progress, potential and pitfalls. BioEssays 29, 188-197.

Wong E. H. K., HANNER R. H., 2008. DNA barcoding detects market substitution in North American seafood. Food Res. Int. 41, 828837.

YANG H. Q., DONG Y. R., GU Z. J., LIANG N., YANG J. B., 2012. A preliminary assessment of matK, rbcL and trnH-psbA as DNA barcodes for Calamus (Arecaceae) species in China with a note on ITS. Ann. Botanici Fennici 49, 5-6.

KOSMOS Vol. 68, 1, 89-96, 2019

ZuZanna Kowalska, Filip PNiEWski, AdAm LataŁa

Institute of Oceanography, Faculty of Oceanography and Geography, University of Gdansk, 46 Pitsudskiego Str., 81-378 Gdynia, E-mail: zuzannakowalskaO@gmail.com

DNA BARCODING - A MODERN APPROACH TO IDENTIFICATION OF ORGANISMS

\section{Summary}

There exists a great many species in the world. Many of them are still undiscovered and undescribed. Traditional techniques of species identification based on their morphological peculriarity and specially designed keys have significant limitations. Therefore, there appear a need for a new approach to taxonomic identification of organisms that would be easy, fast and reliable. Barcoding DNA is the ideal candidate for species identification system based on one or several short DNA sequences characteristic for an organism. It can be used to determine the identity of known species or to describe undiscovered ones. In addition, it can be used in palaeoecology, biodiversity research and in studies on trophic networks. This paper presents the idea underlying DNA barcoding, standard markers used to organisms identification and possible applications of DNA barcodes in science and for practical and commercial purposes.

Key words: biodiversity, DNA barcoding, taxonomy 